\title{
Attitudes to water usage in Jordan
}

\author{
Laura Bolton \\ IDS \\ 12 July 2021
}

\section{Question}

What are the attitudes to water usage in Jordan? In particular:

1) What is the cultural attitude to water?

2) What is considered appropriate and inappropriate usage of water resources?

3) What do Jordanians feel is the role of government in managing water resources- what do they see as their primary role?

4) What individual responsibility do Jordanians feel they have for managing water resources?

5) Is there a generational difference in attitudes to water resources?

\section{Contents}

1. Summary

2. Background

3. Water conservation attitude survey

4. Water quality perceptions

5. Water awareness raising campaigns

6. Water rationing in Amman in 2010

7. Alternative water sources

8. References

The K4D helpdesk service provides brief summaries of current research, evidence, and lessons learned. Helpdesk reports are not rigorous or systematic reviews; they are intended to provide an introduction to the most important evidence related to a research question. They draw on a rapid deskbased review of published literature and consultation with subject specialists. 


\section{Summary}

The research base into attitudes to water usage in Jordan is very small with only a few relevant articles identified in the course of this rapid review. One survey was identified which assessed attitudes towards water conservation, sampling 2000 residents in three regions in Jordan (Irbid, Amman, and Zarqa) in 2017 (USAID, 2017 \& 2018). Only 61\% of respondents believed there was a water shortage in Jordan. $23 \%$ believed the water shortage was due to population pressures. The survey focussed more on water conservation than water use. The three most common water saving methods were turning off the tap, testing water networks, and using water saving devices. Reasons for not saving water include social gatherings, showing off cleanliness, and ignorance.

The survey also asked questions to explore how water information might best be received. Water utility companies were the most trusted source for information, followed closely by the Ministry of Water and Irrigation, and then family and friends. Respondents were concerned that water saving initiatives might cost them time.

Most of the respondents felt the government were not doing enough on water shortage issues. They were not asked how they feel about the role of the government versus their individual responsibility. Older respondents perceived the shortages to be more critical. A lack of interest in participating in water saving activities was identified among the youth. Syrian respondents reflected different water practices than Jordanians although practices became increasingly aligned the longer their residency.

Water quality was perceived as poor in the USAID survey and noted in other sources. Al-Mefleh et al. (2019) find $71 \%$ of respondents surveyed in 200 households in Al-Mafraq consider the water pumped through the public system to be insufficient. A survey in Amman in 2010 found that less than a third of residents use networked water for drinking. Hurlimann \& Dolnicar (2016) find $64 \%$ of the 200 survey respondents consider their current water supply to be bad for their health.

A water awareness campaign run by the USAID Water Management Institute designed by a large advertising company in 2019 was deemed successful. Messaging through religious forums and teachings have been involved in campaigns.

An article on water rationing in 2010 in Amman shows some inequality with higher-income houses having greater storage capacity (Potter et al., 2010). The survey found that most residents had management strategies in place for the day that the water was delivered.

A survey of attitudes to alternative water sources, with 200 participants, found that most considered recycled water to be bad for their health (81\%) (Hurlimann \& Dolnicar, 2016). Rainwater from a tank was considered the cheapest source and the alternative source that was most known about. Only $26 \%$ considered rainwater to be bad for health, although $76 \%$ described it as unclean.

There was little in the published or grey literature which goes into detail of the sub-questions suggesting that primary research would be useful to answer more specifically what Jordanians feel is the role of the government in managing resources and to what extent they feel they have 
personal responsibility. Only one survey looked at intergenerational differences and not in a lot of detail. There was little on gender differences to water attitude and use.

Views about politics of regional cooperation and refugee pressure on water use potentially affect attitudes to water but this was not identified specifically within the scope of this report.

\section{Background}

Jordan is known as a water scarce country and has a widening gap between supply and demand for domestic use as well as use for agriculture and industry (Jeuland et al., 2021). In 2015 the World Resources Institute projected Jordan to be the 14th most water stressed country in the world in 2040. ${ }^{1}$ Currently Jordan supplies around 145 cubic metres per capita per year, expected to fall to 91 cubic metres per year by 2025 (Al-Saidi \& Dehnavi, 2019).

The Zarqa region recorded the greatest water deficit in 2017 pumping 77.5 million more cubic metres than sustainable levels. The Azraq region had a 45.7 million cubic metre deficit, the dead sea area 26.9 and the Disi area 16.6. Hammad and Sirhan were marginally within sustainable limits with a surplus of 6.5 and 5 metre cubed respectively (Whitman, 2019).

Analysis of urban water pricing in Jordan shows deficiencies with regard to economic valuation of water services and the cost recovery of water utilities (Al-Saidi \& Dehnavi, 2019). In major cities where water shortages are common, consumers pay around 4.2 US Dollars (3 Jordanian Dinar) per cubic meter to private vendors operating water tankers (Kis et al., 2017).

\section{Water conservation attitude survey}

In 2017, the USAID Water Management Initiative (WMI) collected baseline information on water conservation attitudes and practices in three cities in Jordan (USAID, 2017; USAID, 2018). 2000 households were sampled across Irbid, Amman, and Zarqa.

Key findings (USAID, 2017):

- $61 \%$ believe there is a water shortage in Jordan

- $23 \%$ believed the shortage was due to population pressures. And $10 \%$ gave the reason 'lack of rainfall'. These were the top two responses.

- The three most common methods for water saving in the home are turning off the tap; testing water networks for leaks and making repairs; and using water saving devices on taps.

- Reasons identified for not saving water include social norms such as household size; prevalence of social gatherings; showing off wealth and cleanliness; and ignorance.

- $30 \%$ of respondents trusted water utility companies the most for water-related information. 27\% trusted the Ministry of Water and Irrigation the most. $26 \%$ said family and friends, $9 \%$ a plumber, and $7 \%$ trusted no one for water-related information.

\footnotetext{
${ }^{1}$ https://www.wri.org/insights/ranking-worlds-most-water-stressed-countries-2040 accessed 7.7.21
} 
- Most respondents were unaware of initiatives related to water usage.

- Respondents were interested in participating in water usage initiatives but concerned about time.

- Focus group discussions raised that social media and internet use is heavily biased towards young people and older people preferred the newspaper. This should be taken into consideration for awareness raising campaigns.

Syrian refugee respondents based in Jordan reflected different water usage practices but that their practices and knowledge become closer to that of Jordanians the longer they have been in the country (USAID, 2018). Many of the Jordanians and Syrians felt that the government is not doing enough and would like to see improved management of water resources, regular maintenance, infrastructure projects and better distribution mechanisms. Survey respondents expressed a need for greater enforcement of regulations and penalties.

There were disparities in responses between age groups, gender, and urban/rural (USAID, 2018). Older respondents perceived the water shortage to be progressively more critical. And Jordanians perceive it to be more of an issue than Syrian inhabitants. Many Jordanians believe the refugee population are causing the shortages whereas Syrians believe it has been a problem for many years related to low rainfall and scarcity of water resources.

A lack of interest in participating in water related activities or initiatives was identified among youth (USAID, 2018). This attitude was apparent in females more than males and in Syrians more than Jordanians. Time constraints and job commitments were given as reasons for lack of interest in participating.

Two thirds of respondents were aware of what constituted illegal water use (USAID, 2018). Illegal practices include "connecting water drainage pipe to the sewage network or connecting the household sewage network to main sewage network without subscription or connecting the household sewage network to rainwater drainage network" (USAID, 2018, p9).

Participants were unsatisfied with water quality and expressed willingness to pay more for better quality water (USAID, 2018).

Water saving methods used by participants were mainly focussed on indoor methods including closing water taps, testing water networks, and using water saving devices in the home (USAID, 2018). Water efficient washing machines were the most used water saving technique. There was a perception that Syrians tended to use water inefficiently when they first arrived as they were not aware of water shortage problems. But adapted when made aware.

Respondents in Irbid were most active in water network maintenance (67.2\% participation) and residents in Zarqa the least active (42.3\% participation) (USAID, 2018). In Amman and Zarqa the national water company were the most trusted source of information whilst in Irbid the Ministry of Water and Irrigation were the most trusted source. 


\section{Water quality perceptions}

A study published in the Water Supply journal used a questionnaire in the Al-Mafraq Governorate of Jordan to capture residents' perceptions of water quality (Al-Mefleh et al., 2019). 200 households were surveyed.

Findings include:

- $71 \%$ find the water pumped through the public system to be insufficient

- $49 \%$ state that water laws and regulations are not implemented efficiently

- $85 \%$ are dependent on groundwater wells

- $42.5 \%$ report issues with water contamination

\section{Water awareness raising campaigns}

In the summer of 2019 , a water conservation campaign was run by the WMI and Miyahuna², Jordans water company (Dergham et al., 2020). The campaign slogan was posted on billboards, newspapers, shown on television and run through social media and was said to reach 3.5 million Jordanians. A large advertiser, Ogilvy ${ }^{3}$, designed the campaign.

Benedict and Hussein (2019) analysed the 2019 MWI Water Efficiency and Public Information for Action (WEPIA) campaign. The authors identify two different types of insecurity discourses used to legitimise state ownership and interference in people's water use. A "state insecurity" discourse suggests that rationing will lead to civil unrest which rationalises a demand-side rather than supply-side approach. And a "citizen insecurity discourse" that ineffective daily water practices worsen water scarcity and so create a security risk to water access. The report notes that the high cost of supplementary water from tanker trucks makes the population aware of the need to conserve water, even among children (p8). Interviews with government officials and NGO practitioners found a tendency to cast responsibility of water management on to citizens.

Benedict and Hussein (2019) look at the connections made by authorities to the religious meanings of water. A WEPIA programme in 2001 first made this link. MWI officials describe messaging linked to the Prophet Muhammad's sayings. Water conservation behaviours were contextualised within religious requirements and messages channelled through religious leaders.

A WMI survey following the campaign found that knowledge of the water crisis had risen and $24 \%$ of the targeted population carried out roof tank checks (Dergham et al., 2020). The WMI are now planning initiatives for long-term behaviour change with an incentive-based programme.

\footnotetext{
${ }^{2}$ https://miyahuna.com.jo/en accessed 1.7.21

${ }^{3}$ https://www.ogilvy.com/ accessed 1.7.21
} 
A campaign of the Millennium Challenge Account Jordan 4 (MCA-Jordan) in 2015 used messaging in mosques on saving water. ${ }^{5}$ The teachings of Islam are found to offer useful advice on behaviours for staying healthy and not to overconsume. MCA-Jordan worked with the Ministry of Islamic Affairs to distribute water awareness messages to women during religious services. The campaign, called 'By Water We Live - We Preserve it to Survive'6 also included knocking on doors, holding public meetings, billboards, brochure distribution, and school visits. Information on the impact of this campaign was not identified.

\section{Water rationing in Amman in $\mathbf{2 0 1 0}$}

Survey research investigating network water rationing in the Greater Amman Municipality in 2010 found the social costs of water rationing to be high among the sample of 50 households (Potter et al., 2010). Although water rationing is no longer in place, the research reflects attitudes to water at this time. Delivery of water once a week meant that storage capacity was important with high-income households having greater storage than low-income households. High-income households were found to use around twice the volume of water that low-income households used. Wealthier households are able to store more water and able to buy water from tankers. High-income households also more regularly purchased bottled water.

Survey respondents were found to have management strategies for the day that water was delivered; " $74 \%$ of households stated that they adopt specific strategies in order to carry out the household tasks at hand on what is commonly referred to as "the day of water", whereby they organise bathing, housework, laundry, cleaning and gardening at a specific time or in a specific way" (Potter et al., 2010, p120). Women tended to take control of management of water use within the home.

Water quality was found to be a major issue. Less than a third of all households used networked water for drinking. Nearly all low-income households use networked water for cooking. All respondents reported incidents of ill-health. Only high-income households were able to use networked water for gardening. Children were educated in the careful use of water.

\section{Alternative water sources}

The Potter et al. (2010) survey research found urban households were less likely to use rooftop rainwater harvesting than rural households. None of the high-income households harvested rainwater. A survey on rainwater harvesting conducted among university students studying natural resource conservation agreed that water conservation was very important in relation to the water shortages faced in Jordan (Abdallah \& Antary, 2021). Al-Mefleh et al. (2019) recommend government incentives for rainwater harvesting.

\footnotetext{
${ }^{4}$ http://www.mca-jordan.gov.jo/ accessed 6.7.21

${ }^{5}$ https://www.mcc.gov/blog/entry/blog-071615-conserving-jordans-critical-water-supply accessed 6.7.21

${ }^{6}$ https://www.mcc.gov/blog/entry/blog-031915-building-grassroots-support-for-water-conservation-in-jordan accessed 6.7.21
} 
The Jordan National Water Strategy of 2016-2025 predicts that desalination and wastewater reuse will increase from $12.8 \%$ (this represents wastewater reuse only as desalination was not in existence at the time of the report) to $34 \%$ of the total use by 2025 (MWI, 2016).

A study looking at the perceptions of alternative water sources in a number of countries included surveying 200 participants from Jordan (Hurlimann \& Dolnicar, 2016). The survey found the most stated drinking water source in Jordan was bottled water ( $67 \%$ of respondents), followed by town supplied water (30\%), and rainwater (19\%). 17\% used recycled water for drinking, $14 \%$ boiled their water, $11 \%$ used groundwater, and $7 \%$ desalinated water for drinking.

Usages of recycled water, desalinated water and rainwater from a tank identified in Hurlimann \& Dolnicar (2016) were mainly watering plants, toilet flushing, cleaning, washing the body and washing clothes. There was a small amount who reported for use in cooking and for drinking.

Table 1 (below) shows further perceptions of different water supplies. Respondents were asked whether they considered each source to be bad for health, expensive, and clean. They were also asked if they knew a lot about the source. Rainwater was considered inexpensive and only $26 \%$ perceived it to be bad for health. $76 \%$ considered rainwater to be clean and $81 \%$ knew a lot about it. The current water supply was perceived worse on each question followed by desalinated water and then recycled water.

Figure 1: Perceptions of alternative water sources

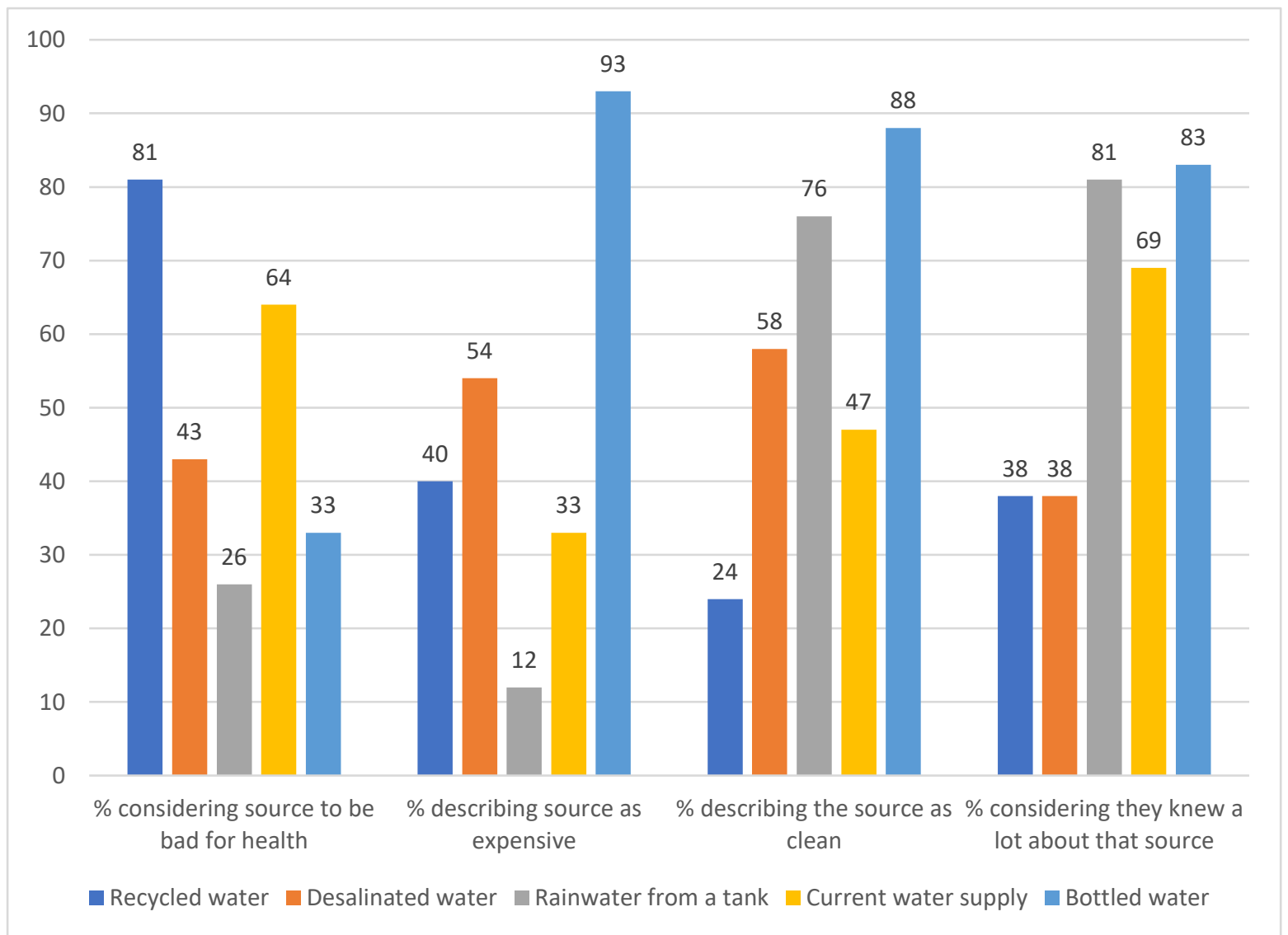

Source: adapted from Hurlimann \& Dolnicar, 2016, p.665,

https://www.tandfonline.com/doi/abs/10.1080/07900627.2016.1143350 


\section{References}

Abdallah, A. L., \& Al Antary, T. M. (2021). Attitudes of students of the University of Jordan towards practicing water harvesting to face the water deficit in Jordan. Fresenius environmental bulletin, 30(1), 678-688. https://www.researchgate.net/profile/Abdelfattah-

Abdallah/publication/346628675_ATTITUDES_OF_STUDENTS_OF_THE_UNIVERSITY_OF _JORDAN_TOWARDS_PRACTICING_WATER_HARVESTING_TO_FACE_THE_WATER_D EFICIT_IN_JORDAN/links/5fca3059a6fdcc697bdba864/ATTITUDES-OF-STUDENTS-OFTHE-UNIVERSITY-OF-JORDAN-TOWARDS-PRACTICING-WATER-HARVESTING-TOFACE-THE-WATER-DEFICIT-IN-JORDAN.pdf

Al-Mefleh, N. K., AlAyyash, S. M., \& Bani Khaled, F. A. (2019). Water management problems and solutions in a residential community of Al-Mafraq city, Jordan. Water Supply, 19(5), 1371-1380. https://iwaponline.com/ws/article/19/5/1371/65384/Water-managementproblems-and-solutions-in-a

Benedict, S., \& Hussein, H. (2019). An analysis of water awareness campaign messaging in the case of Jordan: Water conservation for state security. Water, 11(6), 1156. https://www.mdpi.com/2073-4441/11/6/1156

Dergham, M., Qurashi, S., Favazza, D. (2020). Social Media for Social Good: Raising Awareness of Jordan's Water Crisis. Global Waters, March 2020.

https://www.globalwaters.org/resources/articles/social-media-social-good-raisingawareness-jordans-water-crisis

Hurlimann, A., \& Dolnicar, S. (2016). Public acceptance and perceptions of alternative water sources: a comparative study in nine locations. International Journal of Water Resources Development, 32(4), 650-673.

https://www.tandfonline.com/doi/abs/10.1080/07900627.2016.1143350

Jeuland, M., Moffa, M., \& Alfarra, A. (2021). Water savings from urban infrastructure improvement and wastewater reuse: evidence from Jordan. International Journal of Water Resources Development, 1-20.

https://www.tandfonline.com/doi/abs/10.1080/07900627.2020.1860915

MWI (2016). National Water Strategy of Jordan 2016-2025; Ministry of Water and Irrigation (MWI): Amman, Jordan. http://extwprlegs1.fao.org/docs/pdf/jor156264E.pdf

Kis, A., Abdulla, F., Abu Qdais,H., Ungvári, G. (2016). Water Demand Management in the Context of Water Services-Jordan; Regional Environmental Center for Central and Eastern Europe (REC): Szentendre, Hungary. http://documents.rec.org/publications/WaterDemandManagement_Jordan_May2017.pdf

Potter, R. B., \& Darmame, K. (2010). Contemporary social variations in household water use, management strategies and awareness under conditions of 'water stress': The case of Greater Amman, Jordan. Habitat International, 34(1), 115-124. https://www.sciencedirect.com/science/article/abs/pii/S0197397509000629 
USAID (2017). Knowledge, Attitudes, and Practices Baseline. USAID Water Management Initiative. https://jordankmportal.com/resources/water-management-initiative-wmiknowledge-attitudes-and-practices-baseline

USAID (2018). Implementation of a Population-based Knowledge, Attitudes and Practices (KAP) Baseline Assessment Study. Final KAP Study Findings Report. USAID/Water Management Initiative (WMI) Project. (Not available online).

Whitman, E. (2019). A land without water: the scramble to stop Jordan from running dry. Nature 573, 20-23. https://www.nature.com/articles/d41586-019-02600-w

\section{Acknowledgements}

We thank the following experts who voluntarily provided suggestions for relevant literature or other advice to the author to support the preparation of this report. The content of the report does not necessarily reflect the opinions of any of the experts consulted.

- Julie Johnson, Development Outreach and Communications Specialist, USAID

\section{Suggested citation}

Bolton, L. (2021). Attitudes to water usage in Jordan. K4D Helpdesk Report 1028. Brighton, UK: Institute of Development Studies. DOI: 10.19088/K4D.2021.105

\section{About this report}

This report is based on six days of desk-based research. The K4D research helpdesk provides rapid syntheses of a selection of recent relevant literature and international expert thinking in response to specific questions relating to international development. For any enquiries, contact helpdesk@k4d.info.

K4D services are provided by a consortium of leading organisations working in international development, led by the Institute of Development Studies (IDS), with Education Development Trust, Itad, University of Leeds Nuffield Centre for International Health and Development, Liverpool School of Tropical Medicine (LSTM), University of Birmingham International Development Department (IDD) and the University of Manchester Humanitarian and Conflict Response Institute (HCRI).

This report was prepared for the UK Government's Foreign, Commonwealth and Development Office (FCDO) and its partners in support of pro-poor programmes. Except where otherwise stated, it is licensed for non-commercial purposes under the terms of the Open Government License v3.0. K4D cannot be held responsible for errors, omissions or any consequences arising from the use of information contained in this report. Any views and opinions expressed do not necessarily reflect those of FCDO, K4D or any other contributing organisation.

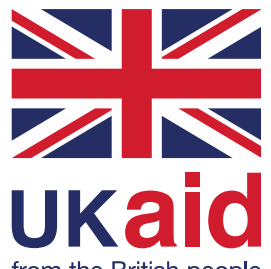

(c) Crown copyright 2021. 